Research Article

\title{
Meningkatkan Kemahiran Mengingat Lima Hukum Asas Tajwid Dalam Tilawah Al- Quran
}

\author{
Muhammad Zulazizi Mohd Nawi ${ }^{1}$, Muhammad Amirul Mohd Nor ${ }^{1}$ \\ ${ }^{1}$ Faculty of Human Sciences, Universitas Pendidikan Sultan Idris, Malaysia.
}

Article History
Received:
01.02 .2021
Revised:
03.04 .2021
Accepted:
11.04.2021
*Corresponding Author:
Muhammad Zulazizi Mohd
Nawi
Email:
zulazizi0902@gmail.com

This is an open access article, licensed under: $\mathrm{CC}-\mathrm{BY}-\mathrm{SA}$
Abstract: Artikel ini bertujuan mengkaji kemahiran mengingat pelajar terhadap lima hukum asas tajwid ketika mentilawahkan al-Quran. Kajian ini menggunakan pendekatan kuantitatif berbentuk ujian pra dan pasca ke atas 10 orang pelajar Tingkatan 2 (DLP) dari Sekolah Menengah Kebangsaan Panglima Bukit Gantang, Parit Buntar, Perak. Sebelum pengkaji memperkenalkan kaedah pengajaran tajwid yang baharu, pengkaji perlu mengesan terlebih dahulu kelemahan pelajar. Tinjauan awal dilakukan dengan menyemak bacaan pelajar ketika waktu pengajaran dan didapati kebanyakan pelajar tidak mampu mengingat lima hukum asas tajwid selain terdapat banyak kesalahan dalam pembacaan. Jadi, pengkaji memperkenalkan kaedah jari tangan kanan bagi memastikan pelajar boleh mengingat lima hukum asas tajwid dan membaca al-Quran dengan baik. Dapatan kajian menunjukkan bahawa, pelajar bukan hanya mampu mengingat hukum-hukum tajwid malah dapat mengkategorikan jenis-jenis bacaan. Dapatan kajian ini juga turut menyumbang kepada maklumat asas mengenai fungsi tanwin ( sakinah (نْ). Kaedah jari tangan kanan mempunyai kelebihan yang tersendiri dan kaedah ini perlu diperluaskan sebagai alat bantu mengajar dalam arus perdana.

Kata Kunci: Kaedah Jari Tangan Kanan, Kemahiran Mengingat, Lima Hukum Asas Tajwid, Tilawah al-Quran.

Enhancing the Skills of Memorizing the Five Basics of Tajweed in Holy Quran Recitation

Abstract: This article aims to study students' memorization skills on the five basics of tajweed when reciting the Quran. This study uses a quantitative approach in the form of pre and post-tests on 10 form 2 students (DLP) from Sekolah Menengah Kebangsaan Panglima Bukit Gantang, Parit Buntar, Perak. Before the researcher introduces a new method of teaching tajweed, the researcher must first detect the weaknesses of the students. A preliminary survey was done by checking students' reciting during teaching sessions and it was found that most students are not able to memorize the five basics of tajweed apart from there are many errors in reciting. So, the researcher introduced the method of the right-hand finger to ensure that students can memorize the five basics of tajweed and recite the holy Quran well. The findings of the study show that students are not only able to memorize tajweed but can also recognize the types of recitation. The findings of this study also contribute to the basic information on the function of tanween (ن) and nun sakinah (ن). The right-handed finger method has its advantages and this method needs to be expanded as a teaching aid in the mainstream.

Keywords: Five Basic of Tajweed, Quran Recitation, Right-Hand Finger Method, Skills of Memorizing. 


\section{Pendahuluan}

Halatuju utama pendidikan al-Quran adalah untuk mendidik manusia agar menyembah dan mengabdikan diri kepada Allah SWT. Menurut Ismail et al. [1], dalam meniti kehidupan pada marcapada ini, mengingat dalam pendidikan al-Quran menjadi pemangkin terhadap pembentukan kognitif fotografi sekaligus menjadi kaedah utama bagi melahirkan generasi al-Quran yang alim dan profesional. Mengingat adalah salah satu alternatif boleh digunakan untuk mendalami ilmu al-Quran. Mengingat merupakan satu proses yang digunakan menyimpan kapasiti maklumat sama ada secara serta merta, jangka pendek ataupun jangka panjang [2]. Bagi Sulaiman [3], mengingat memerlukan keupayaan daya ingatan terhadap orang yang melakukannya. Sementara itu, mengingat sesuatu yang dipelajari dapat melatih mengekalkan kecergasan otak di samping boleh menjauhkan diri daripada penyakit pikun (Alzheimer). Perkara ini dinyatakan sendiri oleh Ibnu Abbas r.a di dalam sebuah hadis yang berbunyi iaitu:

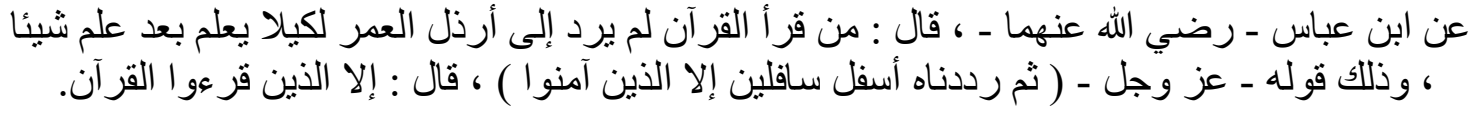

Maksudnya: Daripada Ibnu Abbas r.a telah berkata: Sesiapa membaca al-Quran dia tidak akan

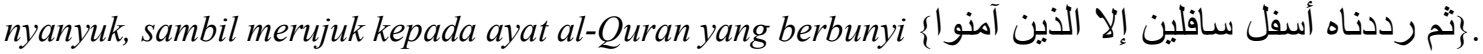
Kata Ibnu Abbas, yang dimaksudkan dengan ayat itu ialah orang-orang yang membaca al-Quran [4].

Al-Quran adalah manual kehidupan dan kitab yang diturunkan oleh Allah SWT sebagai petunjuk bagi umat manusia. Oleh itu, al-Quran hendaklah dibaca, difahami, ditelaah, dikaji, diperkasai dan diimplimentasikan dalam kehidupan agar diri kita benar-benar berada di bawah rahmat-Nya. Maka, antara kaedah yang efektif bagi memastikan seseorang pelajar itu mudah berdamping dengan al-Quran ialah melalui pembelajaran tajwid. Kaedah ini sangat relevan terhadap pelajar kerana fitrahnya yang bersih dan bersedia menerima sesuatu perubahan baharu. Khazanah negara bukanlah perak dan emas akan tetapi pelajarlah merupakan aset yang amat penting untuk kemajuan sesebuah negara. Pelajar juga merupakan generasi penyambung terhadap masyarakat yang mampu mentransformasikan masa depan negara jika berjaya diberikan tindakan dan pendedahan yang sewajarnya.

Realitinya, petikan ayat al-Quran yang perlu dibaca secara bertajwid adalah salah satu elemen yang wujud dalam bahagian tilawah al-Quran. Sukatan pelajaran ini adalah yang pertama dalam Sukatan Muridan Pendidikan Islam pada tahun 2002, kemudian diperkuhkuhkan lagi dalam Kurikulum Standard Sekolah Menengah (KSSM) [5]. Kandungan ini wajib diikuti oleh pelajar-pelajar beragama Islam di sekolah-sekolah menengah. Lazimnya, pelajar wajib menguasai hukum tajwid, beberapa potongan ayat al-Quran dan surah-surah terpilih pada waktu pembelajaran tertentu. Oleh kerana mata pelajaran ini wajib diselesaikan sepanjang waktu persekolahan, maka kualiti bacaan alQuran dan objektif pembelajaran tidak dapat disempurnakan berikutan terlampau rakus ingin menghabiskan silibus [6]. Oleh yang demikian, pengkaji telah memilih beberapa kaedah yang sesuai dan relevan kepada setiap pelajar. Sememangnya, terdapat pelbagai kaedah dalam menguasai ilmuilmu tajwid di dalam al-Quran. Antara yang diamalkan ialah menekankan kepada kaedah berorentasikan pengukuhan serta pemantapan tajwid secara talaqqi dalam setiap kemahiran mengingat. Tanpa kaedah yang munasabah dan terancang, perkara yang dilakukan itu tidak dapat menghasilkan sesuatu yang sempurna. Bacaan al-Quran secara tartil seperti fasohah, makhraj huruf dan tajwid melalui konsep talaqqi adalah satu kaedah utama dalam pendidikan al-Quran. Walau bagaimanapun, kebanyakan pelajar gagal mengimplementasikan elemen-elemen tersebut di dalam pembacaan mereka secara holistik [7].

Sewaktu proses pengajaran dan pembelajaran berlangsung, ghalibnya selepas sesi talaqqi dan musyafahah, pengkaji akan menyemak bacaan pelajar. Ketika inilah pengkaji melakukan sesi soal jawab berkenaan dengan hukum tajwid yang berpandukan ayat-ayat yang dibaca oleh pelajar. Pengkaji mendapati bahawa, kebanyakan pelajar bukan sahaja tidak dapat menjawab setiap soalan dengan betul malah ada yang tidak memahami setiap hukum tajwid. Sebagai contoh, kesalahankesalahan dari aspek sebutan yang wajib dengung dan tidak perlu dengung. Tasmik (bacaan lisan) juga tidak dapat diteruskan kerana terdapat sesetengah pelajar tidak tahu dan gagal menguasai hukum asas tajwid dengan baik. Ada juga dalam kalangan mereka yang boleh mengenal dan memboleh membaca al-Quran. Namun, bacaan mereka sangat mengecewakan kerana mereka tidak prihatin dalam menyebut kalimah dan ayat dengan betul. Situasi ini amat merunsingkan pengkaji kerana 
sekiranya pengkaji membiarkan perkara ini berlanjutan, sudah tentu, mereka akan mengamalkannya hingga akhir hayat mereka. Hal ini bertepatan dengan pandangan Jasmi [8] bahawa, sebagai seorang penuntut ilmu yang beragama Islam, al-Quran perlulah dikuasai sejak kecil lagi bagi memastikan mereka mempunyai kecintaan terhadap Islam dan perjuangannya

Dalam pada itu, satu idea baharu perlu diperkenalkan untuk memastikan kemahiran mengingat ilmu tajwid dapat dilaksanakan dengan efektif iaitu melalui pengaplikasian satu inovasi yang dinamakan sebagai kaedah jari tangan kanan. Kaedah ini menggunakan jari tangan kanan sebagai perantaraan bagi menghuraikan hukum tanwin (ُ) dan nun sakinah (ن்). Kaedah ini disesuaikan dengan jari dan saiz jari supaya pelajar dapat mengingat dan memahami 5 hukum asas tajwid seperti Izhar Halqi, Ikhfak Hakiki, Idgham Bila Ghunnah, Idgham Maal Ghunnah dan Iklab yang. Ibu jari (jari paling pendek) menunjukkan hukum Iklab kerana memiliki satu huruf iaitu iaitu ب (ba) sahaja. Jari kelingking (jari kedua pendek) menunjukkan hukum Idgham Bila Ghunnah atau Idgham tanpa dengung kerana memiliki dua huruf iaitu J (lam) dan $\lrcorner$ (ro). Jari manis (jari ketiga pendek) menunjukkan hukum Idgham Maal Ghunnah atau Idgham bersama dengung memiliki empat huruf iaitu (min) (ya) ن (nun) dan و (wau). Jari telunjuk (jari kedua terpanjang) menunjukkan hukum Izhar Halqi yang bererti jelas di kerongkong mempunyai enam huruf iaitu 1 (alif) $خ$ (kho) $ح$ (kha) $\varepsilon$ (ain) $\dot{\varepsilon}$ (ghin) dan $\bullet$ (ha). Akhir sekali, jari hantu (jari paling panjang) menunjukkan hukum Ikhfa Haqiqi yang membawa maksud menyembunyikan bunyi dari kerongkong menunjukkan bilangan

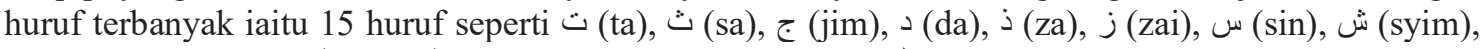

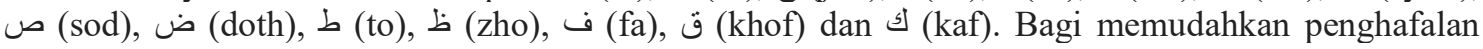
setiap fungsi jari dan hukum-hukum yang mewakilinya, rapatkan tiga jari iaitu ibu jari (Iklab), jari hantu (Ikhfak Haqiqi) dan jari manis (Idgham Maal Ghunnah) agar saling bersentuhan. Ketiga-tiga jari ini mewakili bacaan dengung. Cara bacaan jari kelingking (Idgham Bila Ghunnah) adalah tidak perlu dengung manakala bacaan jari telunjuk (Izhar Halqi) hendaklah nyata dan terang atau jelas.

\section{Objektif dan Persoalan Kajian}

Kajian bertujuan untuk mengenal pasti kemahiran mengingat pelajar terhadap tanwin (ळ) dan nun sakinah (ن) sebelum dan selepas menggunakan kaedah jari tangan kanan. Persoalan kajian pula adalah, adakah terdapat perbezaan yang ketara terhadap kemahiran mengingat pelajar dalam tanwin (்َ) dan nun sakinah (نْ) bagi penggunaan kaedah jari tangan kanan sebelum dan selepas ujian dilakukan?

\section{Sorotan Literatur}

Dalam konteks kajian Jaafar \& Mat Said [9], beliau menjalankan kajian penggunaan kaedah Yadun dalam pembelajaran nun sakinah dan tanwin. Kajian ini berbentuk kuantitatif secara kuasi eksperimen dengan ujian pra dan ujian pasca kepada 58 orang pelajar yang dipilih secara rawak. Hasil kajian mendapati, kaedah Yadun dapat menjadiakan proses pengajaran dan pembelajaran berkaitan dengan nun sakinah dan tanwin (hukum lima) semakin pantas dan mudah. Kajian "Keberkesanan Kaedah alMatien dalam Pembelajaran Tilawah al-Quran" oleh Hussin \& Ismail [10] ini berbentuk kuantitatif ke atas 30 responden, membincangkan aspek penggunaan modul pengajaran al-Quran (Kaedah alMatien) yang menekankan penguasaan bacaan dan tajwid secara bersama. Kajian ini menunjukkan kumpulan eksperimen atau rawatan yang menggunakan Kaedah al-Matien mempunyai perbezaan siginifikan berbanding kumpulan kawalan. Ini menunjukkan kaedah al-Matien perlu diintegrasikan sebagai modul pengajaran al-Quran. Kajian seterusnya daripada Jasmi \& Amin [11] dapat dilihat ketika beliau menjalankan kajian tindakan melalui ujian pra dan pasca (kuantitatif) ke atas 22 orang murid tahun 4 dari SK Kubu Melaka. Pelaksanaan kajian menerusi teknik "Jari Tajwid" dan bahan bantu Kad Jari Tajwid berjaya meningkatkan kefahaman dan penguasaan murid dalam mata pelajaran pendidikan Islam khususnya tajwid al-Quran

Dalam kajian Yuliansyah [12] yang bertajuk "Penggunaan Metode Abjad Jari, Bahasa Tubuh dan Media Pembelajaran dalam Pembelajaran PAI bagi Anak Berkebutuhan Khusus Tunarungu Di Slb Negeri Musi Rawas". adalah bertujuan untuk melihat metodologi abjad jari dan bahasa badan terhadap pembelajaran agama Islam dalam kalangan warga Tunarungu. Kajian kualitatif yang dilakukan secara pemerhatian, temu bual dan analisis dokumen ini mendapati bahawa, penggunaan Metode Abjad Jari dan Bahasa Tubuh dalam kalangan warga Tunarungu serta para siswanya sangat sesuai diterapkan berikutan keperluannya selaras dengan pembelajaran pendidikan Islam. Sementara itu, penggunaan media pula dapat menarik minat pelajar untuk belajar. Berikutnya, kajian Syed Bidin 
et al. [13] berkenaan "Kaedah Pengajaran dan Pembelajaran al-Quran: Kajian Di Masjid Unisza". Kajian ini bertujuan mengenal pasti perkembangan pengajaran dan pembelajaran al-Quran di Malaysia. Kajian ini yang berbentuk kualitatif yakni secara analisis dokumen dan temu bual mendapati kaedah talaqqi musyafahah terus diamalkan, namun dinamika pendekatan yang digunakan untuk melatih pembacaan al-Quran adalah berbeza. Akhir sekali kajian konseptual oleh Jaafar \& Mat Said [14] yang mengkaji mengenai "Aplikasi E- Tajwid Yadun: Inovasi Dalam Pembelajaran Tajwid" mendapati E-tajwid Yadun mampu mewujudkan iklim pembelajaran yang lebih komprehensif dan interaktif selain mampu menguatkan daya ingatan pelajar terhadap hukum-hakam tajwid. Kajian ini merupakan sebuah reka bentuk prototaip yang dibangunkan dan akan dipersembahkan kepada pengguna nanti.

\section{Metodologi Kajian}

Kajian ini adalah kajian kuantitatif yang dilakukan secara ujian pra dan pasca. Populasi kajian adalah pelajar dari Sekolah Menengah Kebangsaan Panglima Bukit Gantang, Parit Buntar, Perak. Responden pula merupakan pelajar tingkatan 2 (DLP) yang terdiri daripada 10 orang pelajar iaitu seramai 5 orang pelajar lelaki dan 5 orang pelajar perempuan (rujuk jadual 1). Pemilihan responden ini dibuat berdasarkan kebolehan mereka mengenal bacaan al-Quran, kendatipun begitu, mereka amat lemah dalam mengingat lima hukum asas tajwid dengan betul dan tepat.

Jadual 1. Senarai Nama Pelajar Tingkatan 2 (DLP)

\begin{tabular}{cc}
\hline Bil. & Nama \\
\hline 1 & Amiera Adlina binti Naim \\
2 & Luqman Hakim bin Mohd Azan \\
3 & Muhamad Harith bin Azman \\
4 & Muhamad Irfan bin Zainal \\
5 & Nur Aishah binti Yusof \\
6 & Siti Maisarah binti Zulkifli \\
7 & Nor Azminda binti Shahrul \\
8 & Muhamad Najmi bin Nizam \\
9 & Nur Alisya binti Rahim \\
10 & Muhamad Faizul bin Fuad \\
\hline
\end{tabular}

Selain itu, kajian ini menggunakan instrumen set soalan ujian pra dan ujian pasca. Set soalan ujian terdiri daripada beberapa potongan ayat hafazan al-Quran iaitu surah Ali Imran ayat 8, 18, 26 dan 27 (rujuk Rajah 1). Matlamat ujian pra dan pasca dilakukan bagi mengenal pasti sama terdapat peningkatan tahap hafalan lima hukum asas tajwid ataupun tidak. Lima hukum asas tajwid terdiri dari segi nama hukum, kriteria huruf hijaiyyah, peranan Tanwin (نَ) dan Nun Sakinah (نْ) serta kaedah bacaan. Hasil dapatan ujian pra dan ujian pasca dianalisis mengikut objektif kajian.

\section{Dapatan Kajian}

\subsection{Hasil Analisis Sebelum Pendedahan Diberikan}

Dalam ujian ini, pengkaji melakukan tasmik (bacaan lisan) ke atas 10 orang pelajar yang terpilih. Setiap pelajar diminta untuk membacakan ayat-ayat tersebut di hadapan pengkaji. Berikut adalah huraian mengenainya:

\subsubsection{Pemerhatian}

Berdasarkan pemerhatian terhadap responden didapati semasa sesi pembacaan al-Quran, guru akan membaca terlebih dahulu dan pelajar mengikutinya. Pelajar diminta membacakan ayat-ayat diberikan secara individu (bergilir-gilir) dan berkumpulan. Pengkaji mendapati, pelajar tidak melakukan kesalahan semasa membaca secara berkumpulan. Walau bagaimanapun, kesilapan bacaan pelajar dapat dikenal pasti apabila pelajar membaca secara individu. Selepas itu, sesi soal jawab dilakukan terhadap pelajar dan didapati kebanyakan pelajar hanya berdiam dan tidak aktif menjawab soalan- 
soalan tajwid berkenaan Tanwin (⿻ீ㇒) dan Nun Sakinah $(\dot{\mathcal{U}})$ walaupun mereka merupakan pelajar yang tahu membaca al-Quran.

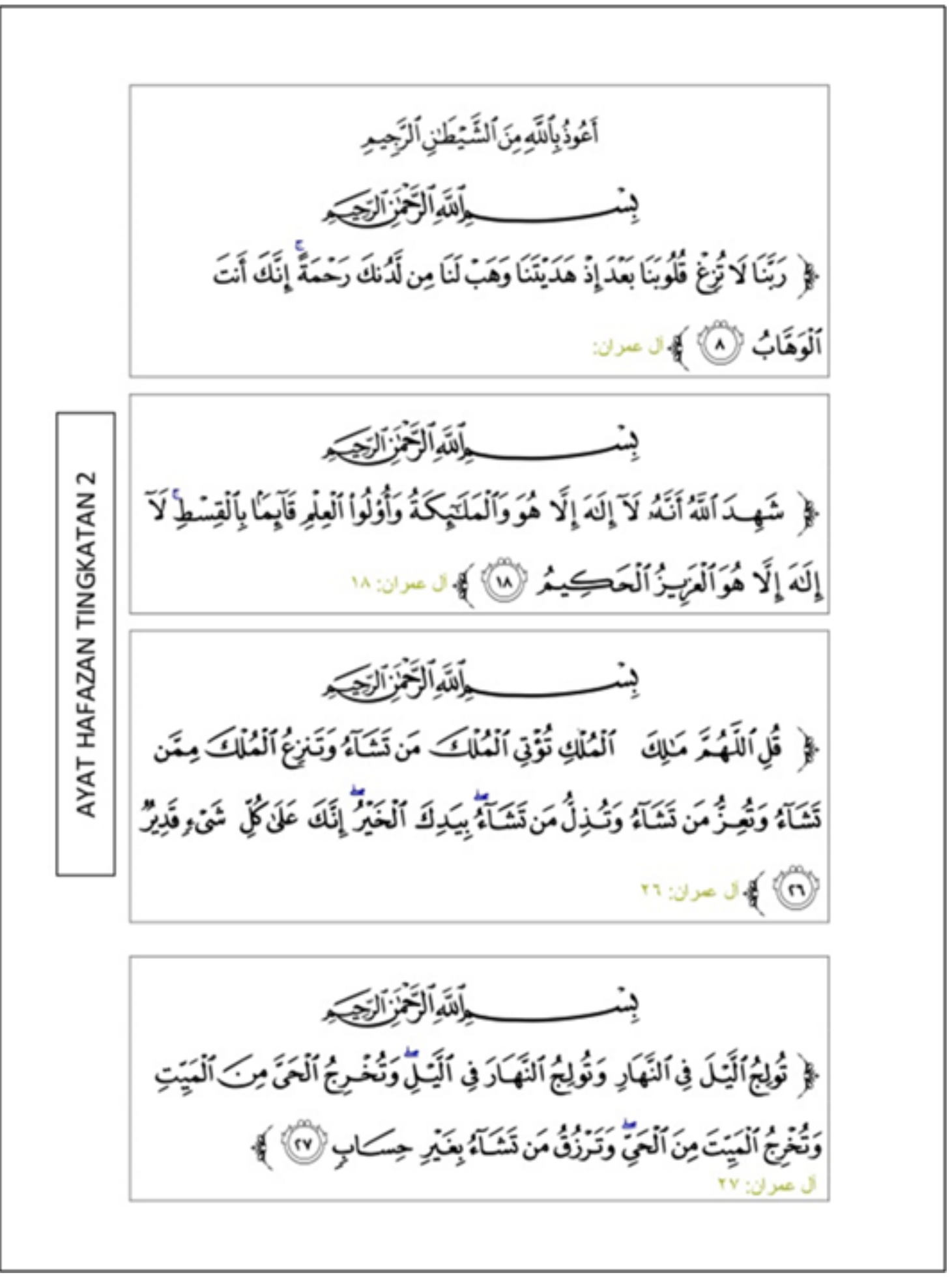

Rajah 1. Surah Ali Imran Ayat 8, 18, 26 dan 27 


\subsubsection{Temu Bual}

Ketika sesi soal jawab tajwid, pengkaji menemubual pelajar dan bertanyakan soalan yakni "kenapakah jawapan yang diberikan oleh awak tidak betul sedangkan awak telahpun mengetahui cara bacaan ayat al-Quran?”. Maka, pengkaji mendapati, setiap jawapan yang diberikan oleh pelajar adalah berlainan seperti mana yang tertera dalam Jadual 2.

Jadual 2. Jawapan Temu Bual Tajwid Pelajar

\begin{tabular}{|c|c|c|}
\hline Jawapan & Kekerapan & Peratusan (\%) \\
\hline $\begin{array}{lll}\text { Tidak } & \text { mengetahui } & \text { fungsi } \\
\text { Tanwin }(-\circ) & \text { dan } & \text { Nun } \\
\text { Sakinah (ن்) } & & \end{array}$ & 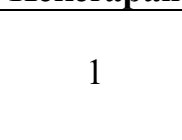 & - \\
\hline $\begin{array}{l}\text { Tidak mengingati setiap nama } 5 \\
\text { hukum asas tajwid }\end{array}$ & 3 & 30 \\
\hline $\begin{array}{l}\text { Tidak mampu mengkategorikan } \\
\text { huruf-huruf hijaiyah dengan } 5 \\
\text { hukum asas tajwid }\end{array}$ & 2 & 20 \\
\hline $\begin{array}{l}\text { Tidak mampu menentukan } \\
\text { kaedah bacaan sama dengung } \\
\text { atau tidak perlu dengung. }\end{array}$ & 4 & 40 \\
\hline
\end{tabular}

\subsubsection{Ujian Semakan Bacaan Al-Quran}

Ujian ini dilakukan terhadap pelajar ketika membaca al-Quran dari surah Ali Imran ayat 8, 18, 26 dan 27. Setiap pelajar diberikan 10 markah bacaan al-Quran dan sekiranya terdapat kesalahan yang dilakukan semasa pembacaan, 1 markah akan dipotong.

Hasilnya berdasarkan Jadual 3, pengkaji mendapati, seramai 4 orang memperoleh 5 markah paling tinggi manakala seorang sahaja memperoleh markah paling rendah. Perkara ini menunjukkan kebanyakan mereka lemah dalam menghafal ilmu tajwid terutama lima hukum asas tajwid dan ini memerlukan penambahbaikan yang holistik.

Jadual 3. Analisis Markah

\begin{tabular}{cc}
\hline Pelajar & Markah \\
\hline 1 & 4 \\
2 & 4 \\
3 & 4 \\
4 & 4 \\
5 & 5 \\
6 & 5 \\
7 & 3 \\
8 & 5 \\
9 & 2 \\
10 & 5 \\
\hline
\end{tabular}

\subsection{Hasil Analisis Selepas Pendedahan Diberikan}

Pada bahagian ini, pengkaji menerangkan hasil keputusan ujian pasca yang diperoleh setelah analisis data kajian dilakukan. Analisis ini dimulakan dengan mengemukakan laporan mengenai hasil pemerhatian dan temu bual daripada responden. 


\subsubsection{Pemerhatian}

Pengkaji memberikan latihan melalui contoh-contoh tajwid bagi meningkatkan kefahaman pelajar seperti tanwin dua baris di atas (), di bawah (9), di hadapan (), nun sakinah yang tidak berbaris (ن) dan berbaris mati $(\dot{\cup})$. Nilai keperihatinan yang ditonjolkan oleh pelajar dapat dilihat menerusi bacaan, sebutan dan keyakinan mereka. Sementara itu, ketika latihan bacaan dengung dan tidak dengung, pelajar menunjukkan sikap dan semangat bagi memperbaiki bacaan mereka.

Guru juga turut menyelitkan unsur-unsur humor (fun learning) menjadikan suasana pembelajaran tajwid bertambah ceria, santai dan tidak membosankan. Keadaan ini bukan sahaja dapat menarik minat pelajar untuk aktif berinteraksi bahkan dapat meningkatkan motivasi dan menjadikan sesi pembelajaran makin positif [15].

Semasa sesi pendedahan kaedah jari tangan kanan, pelajar diajar untuk berimaginasi dan membayangkan mengenai peranan jari jemari serta jumlah huruf hijaiyyah yang ada pada jari bagi memudahkan mereka mengingat lima hukum asas tajwid. Walaupun begitu, terdapat segelintir pelajar yang masih tidak dapat mengingati susunan, fungsi dan nama hukum tajwid melalui jari. Maka, pengkaji memberikan perhatian sepenuhnya terhadap pelajar tersebut selain turut memberikan handout untuk rujukan dan panduan.

\subsubsection{Ujian Semakan Bacaan Al-Quran}

Ujian ini dilakukan sekali lagi terhadap pelajar setelah pelajar diberikan pendedahan mengenai kaedah jari tangan kanan dan latihan-latihan tajwid yang lain. Pelajar juga dikehendaki membaca ayat alQuran dari surah Ali Imran ayat 8, 18, 26 dan 27. Jumlah markah masih dikekalkan iaitu 10 markah bagi keseluruhan bacaan al-Quran dan sekiranya terdapat kesalahan yang dilakukan semasa pembacaan, 1 markah akan dipotong.

Hasilnya berdasarkan Jadual 4, pengkaji mendapati, seramai tiga orang pelajar masing-masing memperoleh 9 dan 8 markah paling tinggi manakala dua orang pelajar sahaja memperoleh 5 markah paling rendah.

Hasil kajian ini menunjukkan peningkatan dalam kemahiran mengingat hukum tajwid dan kebanyakan mereka bukan sekadar boleh mengecam dan memahami bahkan berjaya mengingati setiap peranan kaedah jari tangan kanan dengan cemerlang

Jadual 4. Analisis Markah

\begin{tabular}{cc}
\hline Pelajar & Markah \\
\hline 1 & 8 \\
2 & 6 \\
3 & 9 \\
4 & 8 \\
5 & 7 \\
6 & 7 \\
7 & 5 \\
8 & 6 \\
9 & 5 \\
10 & 7 \\
\hline
\end{tabular}

\subsubsection{Perbandingan Ujian pra dan pasca}

Segala dapatan dikumpulkan dan dibahagikan berpandukan dapatan sebelum dan selepas pendedahan kaedah jari tangan kanan diberikan. Jadual 5 menunjukkan dapatan kumulatif yang dikumpul telah dianalis mengunakan kaedah analisis kuantitatif mudah dan peratus.

Jadual 6 menunjukkan perbandingan dapatan markah purata antara ujian pra dan ujian pasca. Terdapat peningkatan positif terhadap pencapaian markah pelajar. Perkara ini dibuktikan dengan min $(\mathrm{M}=6.8)$ bagi ujian pasca lebih tinggi berbanding $\min (\mathrm{M}=4.1)$ dalam ujian pra. 
Jadual 5. Perbandingan Dapatan Ujian Pra dan Ujian Pos

\begin{tabular}{|c|c|c|c|c|c|c|}
\hline \multicolumn{3}{|c|}{ UJIAN PRA } & \multicolumn{3}{|c|}{ UJIAN PASCA } & \multirow{2}{*}{$\begin{array}{c}\text { Peratus } \\
\text { Peningkatan/ } \\
\text { Penurunan } \\
(\%) \\
\end{array}$} \\
\hline Pelajar & Markah & $\begin{array}{c}\text { Peratus } \\
(\%)\end{array}$ & Pelajar & Markah & $\begin{array}{c}\text { Peratus } \\
(\%)\end{array}$ & \\
\hline 1 & 4 & 9.7 & 1 & 8 & 11.7 & 2 \\
\hline 2 & 4 & 9.7 & 2 & 6 & 8.8 & -0.9 \\
\hline 3 & 4 & 9.7 & 3 & 9 & 13.2 & 3.5 \\
\hline 4 & 4 & 9.7 & 4 & 8 & 11.7 & 2 \\
\hline 5 & 5 & 12.1 & 5 & 7 & 10.2 & -1.9 \\
\hline 6 & 5 & 12.1 & 6 & 7 & 10.2 & -1.9 \\
\hline 7 & 3 & 7.3 & 7 & 5 & 7.3 & 0 \\
\hline 8 & 5 & 12.1 & 8 & 6 & 8.8 & -3.3 \\
\hline 9 & 2 & 4.8 & 9 & 5 & 7.3 & 2.5 \\
\hline 10 & 5 & 12.1 & 10 & 7 & 10.2 & -1.9 \\
\hline
\end{tabular}

*Tanda (-) menunjukkan penurunan

*Tanda $(+)$ menunjukkan peningkatan

Jadual 6. Perbandingan Markah Purata Ujian Pra dan Ujian Pasca

\begin{tabular}{ccc}
\hline Perkara & Ujian pra & Ujian pasca \\
\hline Jumlah & $41 \div 10$ & $68 \div 10$ \\
MIN & $=4.1$ & $=6.8$ \\
\hline
\end{tabular}

\section{Perbincangan}

Kajian ini menunjukkan pencapaian pelajar dalam ujian pra dan ujian pasca. Terdapat perbezaan yang agak ketara dari segi purata markah pelajar yang membaca al-Quran dengan tepat dapat menggambarkan keberkesanan kaedah jari tangan kanan dalam mempelajari lima hukum asas tajwid. Hasil dapatan kajian ini juga menunjukkan bahawa, kaedah jari tangan kanan dapat membantu murid meningkatkan daya ingatan, motivasi dan minat terhadap apa yang dipelajari selain mampu menjadikan iklim pembelajaran lebih harmoni. Dapatan kajian ini selari dengan pandangan Jaafar \& Mat Said [9] yang menyatakan, kekuatan berfikir dan kefahaman akan bertambah selepas inovasi baharu tajwid diperkenalkan.

Seterusnya, dalam kajian ini menunjukkan kepentingan penggunaan dan penerimaan bahan bantu mengajar berbentuk kaedah jari tangan kanan terhadap keberkesanan pembelajaran lima hukum asas tajwid. Penggunaan kaedah jari tangan kanan sebagai alat mengajar dapat mengukuhkan kefahaman pelajar dalam mengingati hukum tajwid kerana pelajar hanya perlu melihat dan membayangkan saiz jari jemari (sama ada panjang atau pendek) bagi mengimbau kembali lima hukum asas tajwid yang diajarkan. Dapatan kajian ini disokong dengan kajian Jasmi \& Amin [11] yang berpandangan bahawa, peningkatan daya tarikan, kefahaman dan keseronokan pembelajaran tajwid sangat bersinambungan dengan bahan mengajar yang disediakan oleh guru.

Pada zaman pendidikan abad ke-21 ini, guru merupakan pencetus transformasi dalam pendidikan dan pembentukan diri pelajar. Amalan pengajaran dalam bilik darjah perlulah dilakukan secara efektif, kritis dan sistematik. Menurut Yuliansyah [12], guru yang kreatif dan inovatif bukan sahaja mampu meningkatkan minat pelajar untuk belajar bahkan objektif pengajaran juga turut akan tercapai. Oleh itu, guru hendaklah memahami idea transformasi ini dengan baik dan menyusun strategi secara rapi bagi memastikan pelaksanaannya dapat dilakukan dengan jayanya. Diharapkan guru-guru mampu 
mencipta pengetahuan baharu bagi mengatasi semua masalah pembelajaran kerana itulah profesion mereka.

\section{Kesimpulan}

Tidak dapat dinafikan bahawa, penentuan kaedah pengajaran dalam pembelajaran memberikan kesan yang sangat besar. Kemungkinan asbab lain seperti silibus mata pelajaran dan ketertarikan pelajar terhadapnya menjadi "tembok besar" kepada keberkesanan pengajaran guru dalam kemahiran mengingat lima hukum asas tajwid, namun impak positif dari penginovasian kaedah jari tangan kanan telah membantu menyelesaikan kepincangan tersebut. Kaedah pengajaran yang relevan dan berdaya maju dalam pembelajaran tajwid amat diperlukan lebih-lebih lagi pendidikan norma baharu yang mempunyai banyak cabaran. Semoga kajian ini mampu membantu para guru pendidikan Islam dan pihak sekolah untuk lebih ke hadapan bagi memenuhi kehendak dan keperluan alat bantu mengajar kontemporari khususnya dalam bidang al-Quran.

\section{Rujukan}

[1] M. J. Ismail, S. Mohamad, T. I. Z. Tengku Puji, and N. H. Yusof, "Strategi Kecemerlangan Institusi Pendidikan Tahfiz Al-Quran Di Malaysia: Satu Tinjauan Literatur,” Jurnal Islam dan Masyarakat Kontemporari, vol. 15, pp. 55-65. 2017.

[2] M. S. Salihin, I. Z. Hashim, N. M. N.Nik Hanafi, F. N.Mansor, and M. A. Mahir, "Penghayatan Muraja'ah Al-Quran Dalam Kalangan Pelajar Tahfiz Al-Quran Dan Al-Qiraat Kolej Universiti Islam Antarabangsa Selangor (Kuis)," in International Research Management \& Innovation Conference (5th IRMIC 2018), 2018.

[3] S. S. Sulaiman, "Kaedah Hafazan: Suatu Tinjauan Ringkas. E-Journal of Islamic Thought and Understanding, vol. 2, no. 1, pp. 44-59. 2018.

[4] Al-Imam al-Hafiz Abi Abdillah Al-Hakim al-Nisaburi, Al-Mustadrak 'Ala al-Sohihayni, j. 2. Beirut: Dar al-Fikr, 1978.

[5] Kementerian Pendidikan Malaysia, Dokumen Standard Kurikulum dan Pentaksiran Pendidikan Islam Tingkatan 2. Bahagian Pembangunan Kurikulum, 2017.

[6] F. Rapihi, "Penggunaan Kaedah Fahamms Surah Asy-Syams Dalam Meningkatkan Kemahiran Menghafaz Surah Asy-Syams," in Seminar Penyelidikan Tindakan Institut Perguruan (IPG) di Kampus Batu Lintang (KBL), pp. 256-267, 2012.

[7] A. Che Mat, A. Awang, and A. N. M. Yaakub, "Tahap Pembacaan Al-Quran Dalam Kalangan Pelajar Di Uitm Terengganu, Asean Journal of Teaching and Learning in Higher Education, vol. 3, no. 2, pp. 82-100, 2011.

[8] K. A. Jasmi, "Membangun Kemahiran al-Quran dan Jawi kepada Anak-Anak (Developing the Skills of the Qur'an and Jawi for Kids)," in Bengkel Pemulihan dan Pengayaan Pengajaran dan Pembelajaran (PdP) al-Quran SRA JAWI (Remedial and Enrichment Workshop for Teaching and Learning Quran SRA JAWI), pp. 1-20, October 2013,

[9] H. H. Jaafar, and M. H. Mat Said, "Kaedah Yadun : Menguasai Hukum Nun Sakinah Dan Tanwin (Hukum Lima) Dengan Mudah Dan Pantas," in Seminar Kebangsaan Pascasiswazah Sains Sosial dan Kemanusiaan (SPSSK 2019), pp. 27-35, 2019.

[10] H. Hussin, and M. Ismail, "Keberkesanan Kaedah al-Matien dalam Pembelajaran Tilawah al Quran, Jurnal al-Turath, vol. 3, no. 2, pp. 1-8, 2018.

[11] N. H. Jasmi, and J. Amin, "Meningkatkan Penguasaanasas Hukum Tajwid Murid Tahun 4 Melalui Kaedah 'Jari Tajwid' \& 'Kad Jari Tajwid," in International Conference on Global Education VII "Humanising Technology for IR 4.0” pada tahun 2019 di Padang Panjang, Sumatera, Indonesia, pp. 1034-1047, 2019.

[12] Yuliansyah, "Penggunaan Metode Abjad Jari Dan Bahasa Tubuh Serta Media Pembelajaran Dalam Pembelajaran Pai Bagi Anak Berkebutuhan Khusus Tunarungu Di SLB Negeri Musi Rawas," A-Bahtsu, vol. 3, no. 1, pp. 73-91, 2018.

[13] S. N. Syed Bidin, M. S. Hamzah, T. Abd Rahman, K. Kamaruddin and N. A. Nik Azman, "Kaedah Pengajaran Dan Pembelajaran Al-Quran: Kajian Di Masjid UNISZA," Jurnal Hadhari, vol. 10, no. 1, pp. 93-108, 2018. 
[14] H. H. Jaafar and M. H. Mat Said, "Aplikasi E- Tajwid Yadun: Inovasi Dalam Pembelajaran Tajwid," in 2nd International Conference On Contemporary Issues In Al-Quran And Hadith 2020 (THIQAH 2020) 21-24 Februari, Indonesia, 27-35. 2020.

[15] S. C. Ismail, "Unsur Didik Hibur Dalam Pdpc," April 2018 [Online]. Available: https://www.pendidik.com.my/2018/04/01/unsur-didik-hibur-dalam-pdpc/. [Accessed: January 2021]. 